\title{
Factors Influencing Supply of Affordable Housing in Nigerian Cities Using Confirmatory Factors Analysis
}

\author{
Taiwo, David Olugbenga \\ Department of Urban and Regional Planning, School of Environmental Studies, The Federal Polytechnic, Ado-Ekiti, Nigeria
}

\section{Siti Hajar Misnan}

Department of Urban and Regional Planning, Faculty of Built Environment and Surveying, Universiti Teknologi Malaysia, 81310, UTM Johor Bahru, Johor

\begin{abstract}
Despite the Nigerian government's efforts to provide affordable housing to the country's low and medium-income groups, the efforts have not yielded the desired results. These have led individuals, families, and organisations to supply housing either on their own or on a rental basis. Although several scholars have attempted to investigate the problem, none has found a realistic solution. Only a few scholars have also used the confirmatory factor analysis to investigate and isolate and the critical factors influencing housing production and supply to the low and medium-income groups in the country. This research attempts to bridge this gap. Ekiti, Lagos and Oyo States were used as case study for the research. Two hundred and ten (210) survey questionnaires were administered on real estate developers using the purposive sampling technique. The data was analysed in SPSS. The study revealed that land accessibility, funding and demographics were found to be the significant factors influencing the supply of low and medium-income housing in the study area. The study recommends direct government intervention in housing supply in favour of an enabling environment for the housing sector in the country.
\end{abstract}

(C) 2020 Penerbit UTM Press. All rights reserved
Received: 17 November 2019

Received in revised form: 21 June 2020

Accepted : 09 August 2020

Published Online : 31 August 2020

\section{Keywords:}

Land Accessibility, Interventions, Affordable Housing, Homeownership

Corresponding Author Contact: taiwo_od@fedpolyado.edu.ng

DOI: $10.11113 /$ ijbes.v7.n3.499

\section{Introduction}

Housing is a basic need and a human right (Obi and Ubani, 2014; Nubi, 2011; Mojdeh and Abdollah, 2013). Housing is an indicator of the individual's standard of living and personality. Invariably, housing has become a priority for the attainment of a decent living standard for both the rural and urban dwellers (Ajibola et al. 2012, Agbola and Adegoke 2006). Additionally, housing is also worthy of attention as it is a crucial sector in the economy (Ademiluyi et al., 2008). Affordable housing is housing that incorporates all essential and fundamental costs and meets the needs of the low and medium-income families (Abelson, 2009). The inability of the majority of the Nigerian population to acquire affordable housing has been of concern to academia and the private sector, especially when it is evident of the wastefulness and the inability of the Nigerian public sector to provide affordable housing for the majority of the population (Henshaw, 2010).

There are, however, global movements that support a private sector driven alternative. In Nigeria, the private sector appears to be the second-largest producer of affordable housing after the individual (Agbola and Kasim, 2007; Taiwo et al., 2017). Hence, the role of the estate developer in the provision of affordable housing to Nigerians is of great importance. The Nigerian government acknowledged this view and has proposed various measures to encourage the private sector assumes the principal role in affordable housing production and supply process. The measures include the formation of Real Estate Developers Association of Nigeria (REDAN), Building Materials Producers Association of Nigeria (BUMPAN). The reduction imposed in the interest rates payable on national housing fund to individuals from 
REDAN and the re-structuring of the housing finance sub-sector to include the presentation of free mortgage markets.

The population of South West Nigeria is 32.5 million and accounts for 21per cent of the total population of Nigeria (NBS, 2012). The size of the population has made it necessary to look into the activities of real estate developers in the region. The region's housing deficit is about 5 million or 29 per cent of the total Nigerian housing deficit (Lagos State Ministry of Physical Planning, 2010). More than 91 per cent of the population of Lagos with a density of about 20,000 people per sq. $\mathrm{km}$ lives in the metropolis (Lagos State Ministry of Physical Planning, 2010). The Lagos metropolis has an occupancy ratio of 8-10 persons per room, and 73 per cent of households occupy a one-room apartment. Overcrowding and homeless has become a norm in the region. Social problems, fire outbreaks and health-related issues are common in most of the urban centres. The housing deficit has caused many issues in the region. Several factors have influenced the provision of affordable housing in the country. These include land accessibility (Nubi, 2008), availability of funding (Akinmoladun and Oluwoye (2007), the demographic status of the people, government interventions (U.N. Habitat, 2011), provision of subsidy (Agbola and Olatubara, 1989), availability of tax breaks and land legislation (Melissa, 2013).

This study examines the factors influencing the supply of affordable housing in Nigerian cities. It uses the confirmatory factors analysis to identify the factors influencing the production and supply of housing to the low and medium-income groups in Nigerian cities. Earlier studies on affordable housing have not identified these critical factors. This study, therefore, bridges this gap.

\subsection{Factors Influencing the Production of Affordable Housing in Nigeria}

Many internal and external factors influence the production of affordable housing in Nigeria. The external factors revolve around the cost of the housing, for example, land procurement (Kuma, 2015), provision of infrastructure in and around the site and adjoining sites, planning and design (Ifesanya 2012), administration and community services (Uganabo, 2011), financing costs, amortisation periods and subsidies (Agbola and Olatubara, 1989). The internal factors primarily refer to the socio-economic situations of the targeted groups or individuals, for example, the monetary and attributes of the group, which is further influenced by employment opportunities, occupation types and wages (Nubi,2008), and the expenditure profiles Ajibola et al., 2012). Besides, factors such as objective gatherings, social characters like family unit or sizes, family structures, needs, traditions, wants and desires, and priorities also play significant roles (Habte, 2010).

\subsection{Global Experiences on Affordable Housing}

Some large urban communities such as in South Africa, Kenya, Tanzania, Thailand, Indonesia and India, the working-class with higher earnings see affordable housing as exceptionally attractive. These working-class from the African or Asian countries who have considerable assets also invest in housing in different nations even though they do not live in these countries. In Africa, the United Nations estimated that, on average, for every new housing unit built in the city, at least ten new families migrate from the rural areas to occupy the new housing unit. The migration into the city for housing compounds the housing supply problem in the cities. One of the consequences of the supply gaps is the pressure generated on house prices and rent levels, with resultant housing stress and non-affordable housing among the low-income households (Gabriel et al., 2005). Research conducted by some scholars (Onibokun, 1990; Aribigbola, 2006; Ibimilua and Ibitoye, 2015), concluded that housing problems occur in almost all countries. Developed countries still have pockets of isolated homeless people, just as the case in developing countries.

Making housing accessible and affordable to the urban population has been a continuous struggle for the government of Nigeria, both at the Federal and the State levels. The shortage of affordable housing has created urban slums and overcrowding in the cities. Table 1 shows the various government plans and efforts to increase the supply of housing in Nigeria. However, from 1962 to 1996 , the achievement rate was just 17 per cent, and the shortfall is over half a million housing units. In 2001, the total housing units in Nigeria was 15,221,000 (UN-Habitat, 2001) while in 2006, the total housing stock was 28,197,085 units (NPC 2010). It was estimated that by 2020 , the country's housing needs is 102,111,081 units (Onibokun, 1990). At present, the country's housing deficit is estimated at 17 million units (Centre for Affordable Housing in Africa, 2015). Therefore, there is needs to produce 800,000 per annum as against the current 100,000 per annum (Centre for Affordable Housing in Africa, 2015).

On the global scale, the housing industry in the Philippines strongly believes that every Filipino family has the right to live with dignity in the comfort of one's own home, irrespective of their economic status. The industry strives to eliminate the deficit of 3.9 million in the housing sector by the year 2030. Therefore, the country has generated and mobilised funds for end-user financing, improved the regulatory environment for housing development and implemented a comprehensive government housing subsidy for targeted groups. Namely, the country has vigorously pursued the low-cost, socialised and economic housing unit (World Bank Group, 2015). In Indonesia, where about 70 per cent of the total workforce is in the informal sector i.e. noncredit worthy enterprises (Utmo, 2014), the vast majority of lowincome housing is self-help housing, which is incremental housing based on financial ability. To address the housing need in the country, the government embarked on multi-story low-income rental housing, unique purpose house, quality improvement of self-help housing and neighbourhood improvements, and the establishment of housing microfinance institutions and secondary 
Table 1 Past Government Achievements in the Housing Sector in Nigeria

\begin{tabular}{|c|l|l|l|l|l|}
\hline \multirow{2}{*}{ Plan Period } & \multirow{2}{*}{ Target } & \multicolumn{2}{|l|}{ Achievement } & \multicolumn{2}{l|}{ Shortfall } \\
\cline { 3 - 6 } & & Units & $\%$ & Units & $\%$ \\
\hline $\mathbf{1}^{\text {st }}$ NDP (1962-68) & 61,000 & 500 & 0.8 & 60.500 & 99.2 \\
\hline $\mathbf{2}^{\text {nd }}$ NDP (1970-74) & 59,000 & 17,700 & 30 & 41,300 & 70 \\
\hline $3^{\text {rd }}$ NDP (1975-80) & 202,000 & 28,500 & 14 & 173,500 & 86 \\
\hline $\mathbf{4}^{\text {th }}$ NDP (1980-85) & 200,000 & 47,200 & 24 & 152,800 & 76 \\
\hline $\mathbf{1 9 9 4 - 1 9 9 6 ~ R o l l i n g ~ P l a n ~}^{199}$ & 121,000 & 17,792 & 15 & 103,208 & 85 \\
\hline Total & 643,000 & 111,692 & 17.3 & 531,308 & 82.7 \\
\hline
\end{tabular}

mortgage facility corporations. To address affordable housing issues in Malaysia, the government set up housing strategies through a consecutive five years' agenda. The agenda includes low cost and affordable public housing programmes such as Projek Perumahan Rakyat that's created purposely for the middle-income households in central urban areas. Hence, Projek Perumahan Rakyat 1 Malaysia (PR1MA) and My First Home Scheme designed to help young adults who have just entered the workforce to purchase their first residential property with 100 per cent financing from financial institutions (Samad et al., 2016). The My Home Scheme, initiated for the low-income group, saw the involvement of the private developers in building lower-cost housing. The Rumah Mesra programme made possible with the aid of government subsidies targets low-income groups.

In several Europeans countries like Bulgaria, Estonia, Hungary, Lithuania Latvia and Slovakia, the local authorities provide social housing for the people in need. More recently, in Austria, Greece, Germany, Italy and Spain, other entities such as communal developers and private owners, public companies or non-profit or limited profit associations, companies and cooperatives provide social housing. In Romania, housing for its population was achieved with public funding (Alpopi et al., 2014). In South America, for example, Columbia, the self-help program was used to addressing housing supply, where the government assist the people through tax-breaks to increase housing supply and to deal with the problem of affordable housing. Other strategies include employer engagement, where employers could support local or regional efforts to increase housing supply. In the attempt to supply more housing, preservation of existing housing is considered critical. The country went further as to build new residential neighbourhoods on underused land near metro stations; construct high-density residential and mixed-use development along transportation corridors. This approach recognises that transportation offers people greater access to jobs, and reflects the importance of the cost of transportation in affordable housing. Besides, such an approach is likely to limit the opposition of the community (Blumenthal et al., 2016).

In North America, for example, in Mexico, housing development is private sector driven characterised by massive housing construction. The strategy used was to design an integrated housing policy. Other strategies include improved inter- institutional coordination, procurement of dignified housing for all Mexicans, the planned reduction of housing deficit and the implementation of a transition towards an intelligent, sustainable urban development model. The creation of the national registry of land reserves which was meant to provide certainty to developers regarding the land location was also put to use. Others include a subsidy program which was usually published six months before its commencement, and the strengthening of institutions that have a direct bearing on housing through loan guarantee, financing, and increased budgetary allocation for housing subsidy program (World Bank Group, 2014).

In addressing the housing supply issues in many countries of Africa and South Africa, attention shifted from state involvement in the provision of housing towards a support approach housing supply. The ad-hoc exploration of alternative approaches led to the emergence of the aided self-help movement. This strategy implicitly shifts housing supply away from state housing provision to a support approach system for housing. Other methods include the site and services and settlement upgrading schemes (Lombard, 1996).

\subsection{Affordable Housing Strategies and Issues in Nigeria}

Nigeria's housing strategies are similar to those adopted in some South American countries. Several affordable housing schemes exist in Nigeria which is either fully funded by the government or in partnership with the government under the public-private partnership (PPP) schemes, site and services schemes and the lowcost housing undertaken during the Shagari era. Depending on the prevailing situation, some selected developers were given concessions by the government to provide affordable housing, as was the case of the Federal Capital Territory (Jibril, 2009; Makinde, 2014).

It has become challenging for private financial institutions to grant loans to the people in most of the emerging industrialised and third world countries. Low per capita earnings and the absence of job security has made these financial institutions either unwilling or not able to grant long term credit facilities to accelerate the development of the urban owner-occupied sector (Dung-Gwon and Mallo, 2011). Additionally, these governments are also faced with scarcity and shortage of funds and other resources to supply 
housing on a scale large enough to match the needs of the low and middle-income households (Balchin and Rhoden, 2002). Therefore, based on the above concerns, the objective of the study is to identify various factors affecting the supply of affordable housing in Nigeria as perceived by the real estate developers using confirmatory factor analysis.

\section{Methodology}

\subsection{Theoretical Dimensions}

The study adopts the Symbolic Interactionism theory approach to highlight the potentials of factors influencing the supply of affordable housing in Nigeria as perceived by real estate developers. Symbolic interactionism is a social theory, which states that human beings act towards social objects in terms of the meaning or symbolism they attribute to those objects, rather than the actual objects' or intrinsic value or character (McClelland, 2005; Carter and Fuller, 2015). The theory is used to explain that with all the challenges facing the housing sector, individuals still desired to own or rent a house because of the primary role it plays. Therefore, in relation to the factors influencing the supply of affordable housing in Nigeria, the study applies the conceptual framework (Figure 1) where affordable housing is the independent variable with two sub-variables or dimensions of (1) Government Intervention which also function through tax breaks and provision of subsidy and (2) Affordable Housing Supply Factors with three dimensions: land accessibility, availability of funding, and demographics. The dependent variable is homeownership. The required data will be derived from real estate developers.

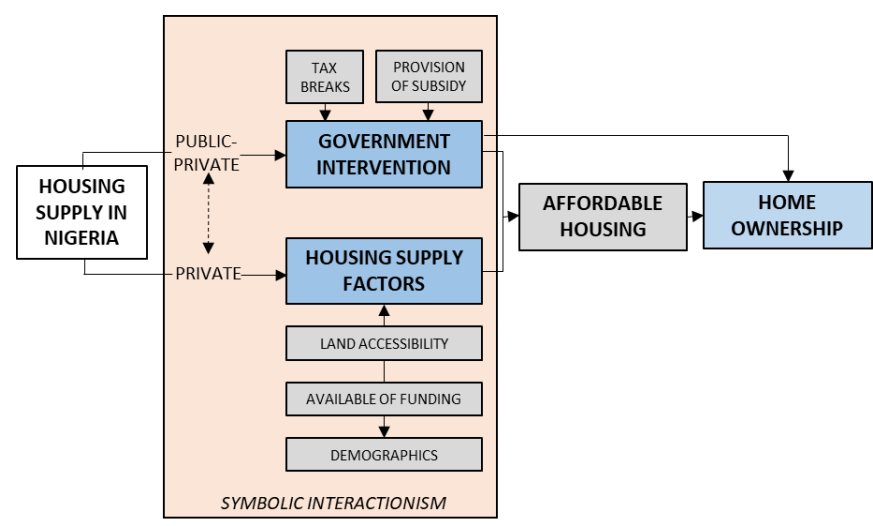

Figure 1 Theoretical Framework

\subsection{Area of Study and Data Collection}

The instrument used for the survey was a questionnaire, and the sampling frame was real estate developers registered with the Real Estate Developers Association of Nigeria (REDAN). A total of 210 questionnaires were administered on the top management levels of real estate developers in south-western Nigeria, namely the states of Ekiti, Oyo and Lagos as depicted in Figure 2 and Table 2.

\subsection{Instrument Reliability and Method of Data Analysis}

Two hundred and two questionnaires were returned and found useable for analysis. SPSS Version 22.0 and the SEM/Amos software were used for the analysis. Examination and screening of data were carried out to test for normality leading to $80 \%$ at $\mathrm{z}$ value \pm 1.96 . Additionally, outliers were deleted and exploratory factor analysis conducted. The Bartlett's test of Sphericity, KaiserMeyer-Olkin was 0.726 and was found to be adequate for further study, as shown in Table 3. All the Cronbach Alpha met the threshold $\geq 0.7$ i.e. Homeownership (0.700), Government intervention (0.875), Tax break (0.871), provision of subsidy (0.718), Land accessibility (0.880), Funding 0.883, and Demographics $(0.756)$; and were found to have right internal consistency. The structural equation models (SEM) was used in furtherance to the exploratory factor analysis. SEM is a secondgeneration multivariate analysis technique developed to overcome some limitations in the traditional Ordinary Least Square (OLS), especially when dealing with latent constructs. The use of SEM/AMOS is increasingly popular among researchers and academia due to the need to develop theories concerning the relationship among certain hypothetical constructs.

Based on Awang (2014), this research complied with the recommendations that confirmatory factor analysis (CFA) be utilised to discover the construct validity of the instrument used. The verification of observed variables can be done using the confirmatory factor analysis (CFA). Confirmatory factor analysis usually (CFA) is a statistical technique which is used to verify the factor structure of a set of observed variables.

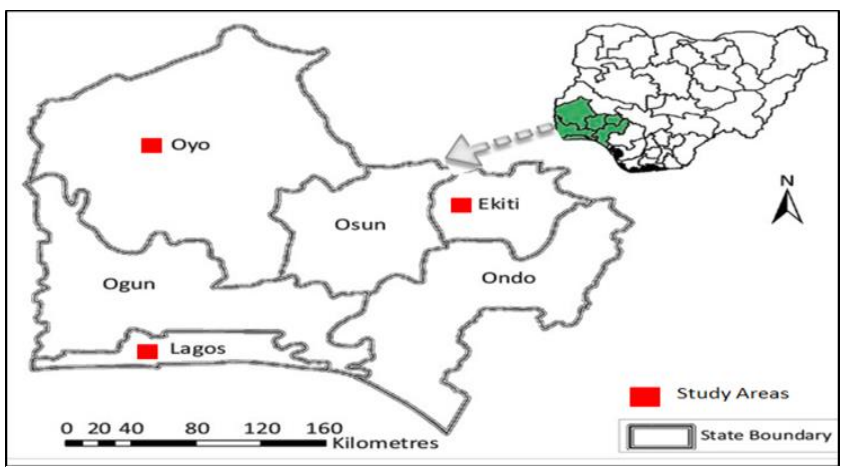

Figure 2 Map of South-West Nigeria showing the selected three states (Taiwo, 2018)

The CFA gives room to the researcher to test the hypothesis for association between the measured and the latent constructs Data gathered for this research were therefore quantified; in essence, prominence was given to the quantitative approach based on the data collected through the use of questionnaire administration. 
Table 2 Sampling Frame of Real Estate Developers

\begin{tabular}{|l|l|l|l|}
\hline \multirow{2}{*}{$\mathbf{S} / \mathbf{N}$} & \multirow{2}{*}{ State } & \multicolumn{2}{|c|}{ Developers } \\
\cline { 3 - 4 } & & No of Developers & Sample \\
\hline $\mathbf{1}$ & Ekiti & 36 & 16 \\
\hline $\mathbf{2}$ & Oyo & 25 & 12 \\
\hline $\mathbf{3}$ & Lagos & 407 & 182 \\
\hline Total & & $\mathbf{4 6 8}$ & $\mathbf{2 1 0}$ \\
\hline
\end{tabular}

Table 3 Kaiser-Meyer-Olkin Measure of Sampling Adequacy

\begin{tabular}{|c|c|c|}
\hline \multicolumn{3}{|l|}{ KMO and Bartlett's Test } \\
\hline \multicolumn{2}{|c|}{ Kaiser-Meyer-Olkin Measure of Sampling Adequacy } & 0.726 \\
\hline \multirow{3}{*}{ Bartlett's Test of Sphericity } & Approx. Chi-Square & 17715.897 \\
\hline & & 1596 \\
\hline & Sig. & .000 \\
\hline
\end{tabular}

It was considered that quantitative measures would usefully supplement and extend the qualitative analysis. Score values below 0.3 as recommended were deleted and those above 0.3 were retained for exploratory and confirmatory analysis. The first stage entails the development of a measurement model using confirmatory factor analysis to obtain the best fitting group of items to represent each constructs scale computed. SEM/AMOS allows for modelling theorised relationships with the sole aim of testing a theoretical model with the empirical data gathered from the field. In AMOS Graphics, the rectangles represent the observed variables, while the ellipses represent the latent constructs. The research questions for the study include; what factors affect affordable housing supply in Nigeria, to what extent have these factors influence affordable housing in Nigeria? The research is limited to land accessibility, funding availability, demographics, government interventions, tax breaks and availability of subsidy in the provision of affordable housing which were derived from the extensive literature reviews through the use of exploratory factor analysis (EFA) and later the application of confirmatory factor analysis.

\section{Results and Discussion}

A total of 202 out of the 210 questionnaires administered on the real estate developers were retrieved and found useable for analysis, hence, a response rate of 96 per cent and met the approximate 75 per cent response rate for interviews, as suggested by Kelly et al. (2003). The top management level of the real estate developers is the primary respondents to the questionnaire administration. The research found that 28 per cent of the real estate developers had established their private practice during 2000 and 2005 period. A majority of the real estate developers, 54 per cent, were established between the year 2006 and 2016. This period marked the beginning of much awareness about the real estate developers' contributions to the provision of housing. The scenario led to the establishment of the Real Estate Developers
Association of Nigeria (REDAN). A tiny proportion, about 1 per cent of the developers, declined to disclose the year of their establishment.

Most of the participants employed by the real estate developers were direct labour, and subcontractors hired some. Majority of the respondents were on the pay-roll of developers. The research also found that 36 per cent of the real estate developers had a workforce of 1-10 staff, 26 per cent with between 11-20 workforce and 14 per cent have a workforce of 21-40 people, respectively. However, Companies with a workforce of more than 40 people accounts for about 23 per cent. The real estate developers were also sources of employment for several professionals and administrative staff, other than the skilled and unskilled labour. The research further found that from the 202 developers interviewed, a total of 9,463 employment opportunities were created and these are as follows: professionals 24 per cent, administrative staff 17 per cent, skilled labour 19 per cent, while, unskilled labour constituted 40 per cent.

With regards to the professional affiliations of the respondents, the Nigerian Institution of Estate Surveyors and Valuers' members (NIESV) accounted for 45 per cent, the Architects Registration Council of Nigeria (ARCON) members 14 per cent, the Nigerian Institution of Building (NIOB) 7 per cent and the Nigerian Institution of Quantity Surveyors 12 per cent. Twenty-two per cent belonged to other related fields in engineering. Fifty-two per cent of the real estate developers are registered with the Real Estate Developers Association of Nigeria (REDAN), the umbrella association of practising developers, while, 48 per cent are not registered with REDAN.

On the number of projects so far undertaken by the real estate developers, 23 per cent disclosed that they had taken less than five projects from their inception, 15 per cent had done 5-9 projects, 17 per cent had between 10 and 14 projects, 39 per cent between 15-19 projects from the time of their establishment. A majority of 
the real estate developers did not have many projects to handle. This could probably be due to factors such as the scarcity of funds and other social and economic factors. Housing projects are capital intensive, and in order to deliver quality housing, much capital is needed. Real estate developers disclosed that they obtained loans from Banks when sourcing for funds. The inability of the private and public developers to have access to mortgage financing contributed to their failure to meet the housing demand of the masses.

Forty-nine per cent of the housing units built were blocks of flats, 31 per cent were duplexes, 7 per cent were detached housing, 10 per cents were semi-detached housing and rooming housing accounts for 3 per cent. The value of the projects handled by the real estate developers was as follows; the value of less than USD3, 174.60 accounted for 16 per cent, between USD3, 174.60USD76,190.47 was 39 per cent, and projects valued between USD 79,365.08- USD107, 936.51 accounted for 14 per cent. About 30 per cent had undertaken projects valued between USD111,111.11- USD139,682.53 and only 1 per cent had handled projects worth more than USD142,857.14. The findings above stipulate that the availability of funds for the real estate developers to embark on the construction of affordable houses were scarce, insufficient or limited. The average cost of a flat of less than USD9, 523.81 constructed by the real estate developers accounts for 69 per cent, a duplex house of USD19, 047.62 was 15 per cent, a detached house of USD15, 873.02 was 6 per cent, semi-detached of less than USD15, 873.02 was 5 per cent and a rooming home of USD15, 873.02 was 5 per cent.

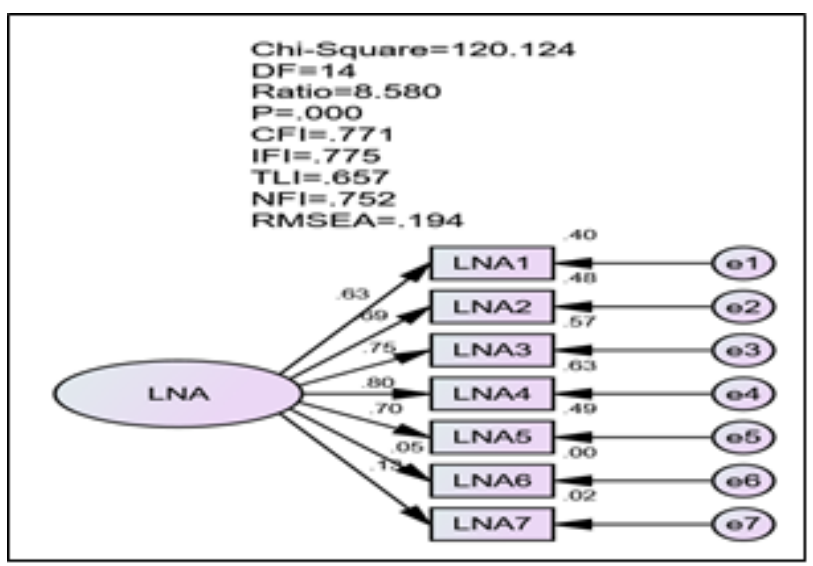

Figure 3a Initial CFA of Land Accessibility

Despite the low economic condition of the population, a majority of the clients of the real estate developers were private individuals who account for 45 per cent. In comparison, corporate organisations constituted 28 per cent. The Federal Government is one of the major clients of the real estate developers and accounts for 16 per cent while state and local government accounted for 10 per cent and 2 per cent respectively. Fifty-one per cent of houses built by the real estate developers are for sale, and 49 per cent were built as rental housing.

The primary source of funding for the real estate developers was loaned from banks ( 55 per cent) which, in most cases, were with high-interest rates and other stringent conditions. The research also found that 3 per cent of the real estate developers borrowed from friends to fund their projects whenever the need arises. The cooperative societies which account for 13 per cent are also another channel available to real estate developers to raise funds to finance housing projects. Personal savings account for 21 per cent, and clients' funds accounted for 8 per cent

In Nigeria, the various approach to the supply of affordable housing yielded little success. The 17 million housing deficit remains as it is for the country. In addition, the upward trends in real house prices have been driven primarily by the interaction of population growth, increase in household income, cheap and available credit, and the unresponsive supply of land on which to build the housing units. A result of which is the general upward trend in house prices, which has significantly affected affordable housing, both for intending home buyers and potentials renters.

Previous studies on affordable housing have based their criteria for the selection of approaches to address affordable housing problems on income and expenditure ratios (Hulshanki, 1995; Gan and hall, 2009; William, 2011; Bramley, 2012; Heylen and Halfiner, 2013). Based on this premise, this research has launched an investigation into other inputs such as housing subsidies and tax breaks. Much attention should be shifted to the factors to improve the supply of housing and increase the homeownership rate in the country. The research also revealed that most of the factors are mentioned or described in qualitative terms rather than in quantitative terms (Agbola, 1988; Akinmoladun and Oluwoye, 2007; EmekaOkereke, 2015).

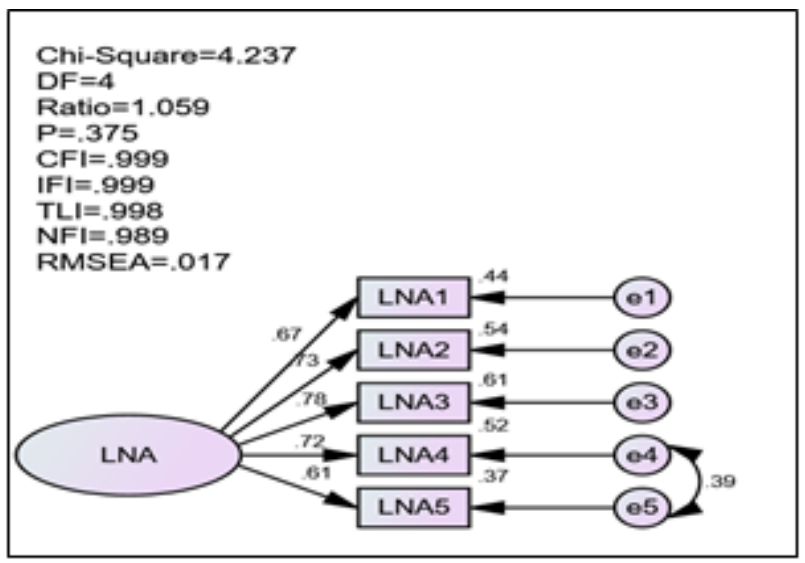

Figure 3b Revised CFA of Land Accessibility

The strength of the current research lies in the deployment of the confirmatory factor analysis to confirm the identified factors. The application of confirmatory factor analysis to the study of affordable housing problems will bring about a better understanding and improvement in the housing supply process. Therefore, the identification of the housing supply factors is critical to developing a new set of alternatives for sustainable housing supply in Nigeria. The verification of observed variables for the research was done using the confirmatory factor analysis (CFA). The CFA allows the researcher to test the hypothesis for the association between the measured and the latent constructs depending on certain conditions. The conditions are listed as 
follows (ii) the modification indices such as CFI, IFI, TLI must be above 0.90 , (iii) the Ratio of the Chi-square and the degree of freedom (df) must range from as high as 5.0 to as low as 2.0 (Tabachnick and Fidell, 2007) and (iv) RMSEA $<0.08$ (Wheaton et al., 1977).

\subsection{Confirmatory Factor Analysis: Land Accessibility}

In the case of Land Accessibility (LNA), the initial CFA model did not comply with the goodness model fit criteria due to the high ratio, which exceeded the recommended 5.0 The Root Mean Square Error Approximation (RMSEA) also indicated that the models model did not provide a good fit for the data at hand, as indicated in Figure 3a and Figure 3b. Consequently, the revised CFA based on the real estate developers is shown in Figure 3b.

In this case, items LNA6 and LNA7 were trimmed due to poor factor loadings. To improve the measurement model, items e4 and e5 were co-varied. After re-specifying the model, it was revealed that the; Chi-square=4.237; $\mathrm{DF}=4$, Ratio=1.059.782, $\mathrm{P}=.375$, $\mathrm{CFI}=.999, \mathrm{IFI}=.999, \mathrm{TLI}=.998, \mathrm{NFI}=.989$ and the $\mathrm{RMSEA}=$ .017 respectively.

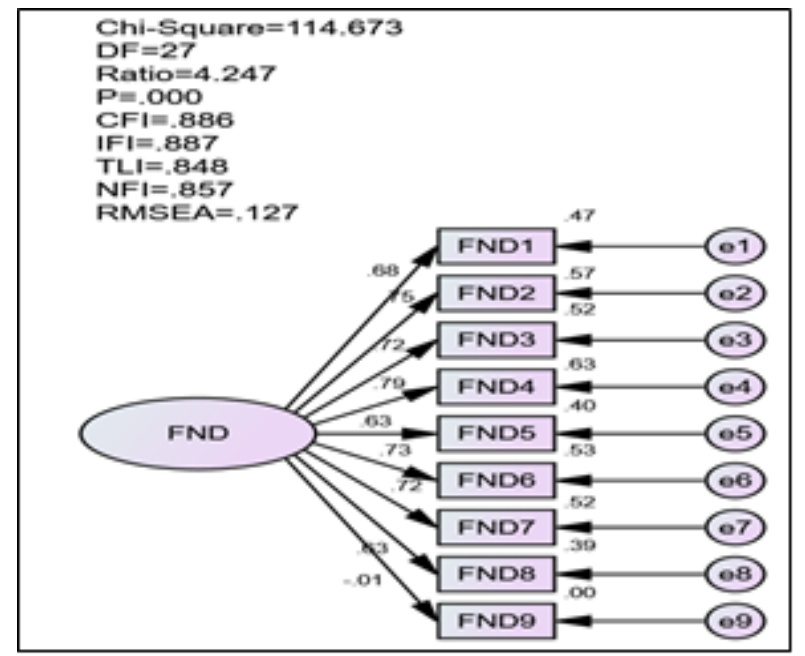

Figure 4a Initial CFA of Funding

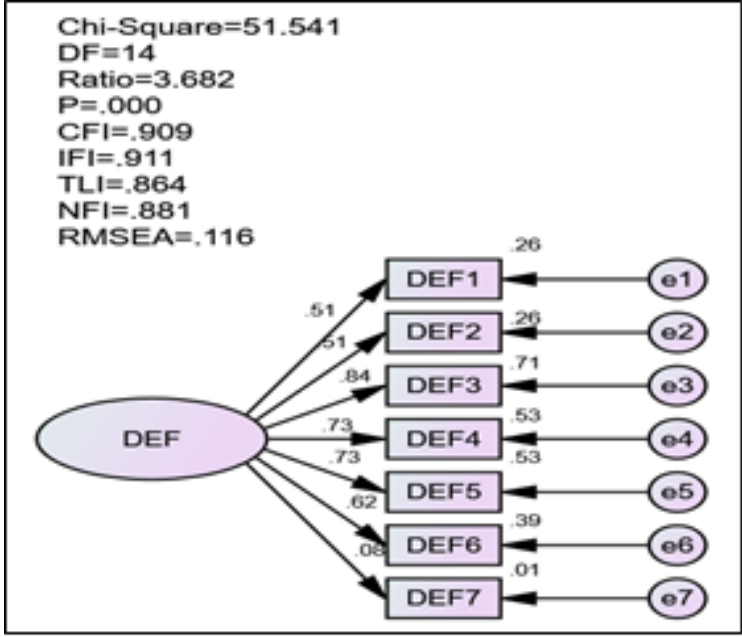

Figure 5a Initial CFA of Demographics

\subsection{Confirmatory Factor Analysis: Availability of Funding}

The initial CFA of Funding model failed to meet the goodness of fit criteria. The CFI, IFI, TLI NFI and the Root Mean Square Error Approximation (RMSEA), also indicated that the model did not provide a good fit for the data as shown in Fig 4a and 4b. The revised CFA models based on the real estate developers are shown in Figure $4 \mathrm{~b}$. In this case, items FND1, FND2 and FND 3 were covaried sequentially to improve the goodness of fit criteria. he Chi-square $=36.187, \mathrm{DF}=16$, Ratio $=2.262, \mathrm{P}=.003, \mathrm{CFI}=.974$, $\mathrm{IFI}=.974, \mathrm{TLI}=.954, \mathrm{NFI}=.955$ and the $\mathrm{RMSEA}=.079$

\subsection{Confirmatory Factor Analysis: Demographics}

On Demographics, Figures $5 \mathrm{a}$ and $5 \mathrm{~b}$ show the CFA of demographics as a factor affecting affordable housing based on the responses of the participants' real estate developers. Items considered are as follows: DEF1- level of income/social status encourage construction of affordable houses, DEF2- closeness of

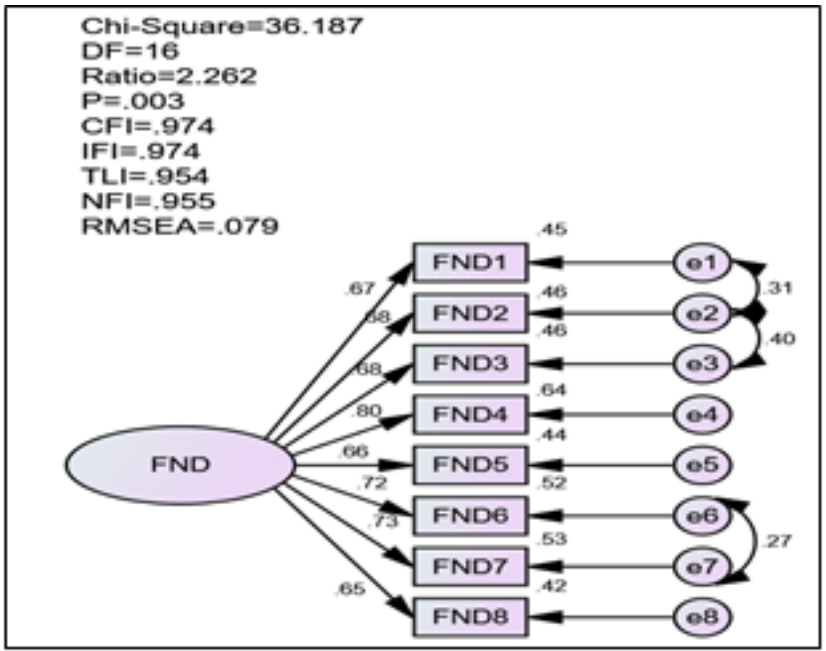

Figure 4b Revised CFA of Funding

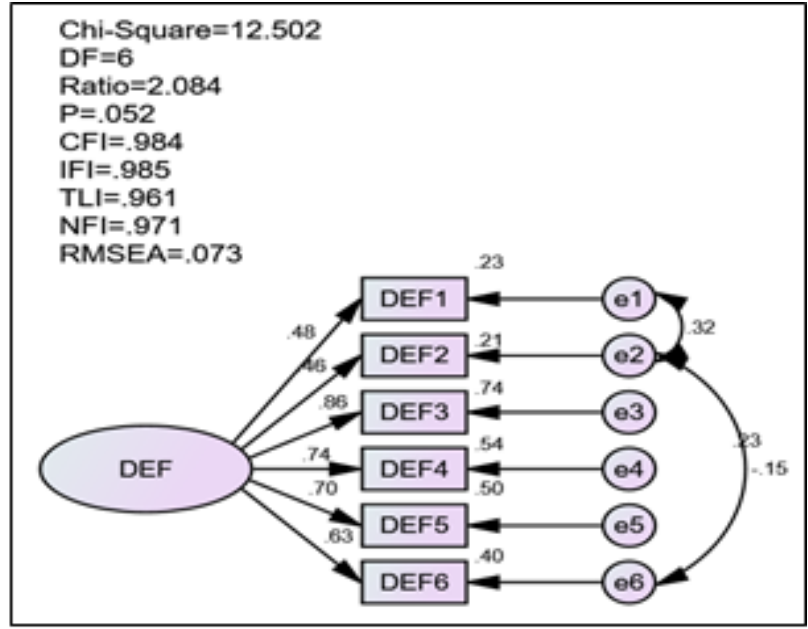

Figure 5b Revised CFA of Demographics 
families' increase demand for affordable houses DEF3- household size determines the choice of household's house type, DEF4cultural values demand the construction of affordable homes, DEF5 - rate of the household formation increases the demand for affordable houses. DEF6- age of head of household has an influence on the construction of affordable homes DEF7- marital status influences the construction of affordable housing.

The initial CFA of this construct did not meet the goodness of fit criteria where, $\mathrm{TLI}=.864$ and $\mathrm{NFI}=.881$, RMSEA .116. The values obtained after modifications to the demographic constructs are; Chi-square $=12.502, \mathrm{DF}=6, \mathrm{Ratio}=2.084, \mathrm{P}=.052, \mathrm{CFI}=$ $.984, \mathrm{IFI}=.985, \mathrm{TLI}=.961, \mathrm{NFI}=.971$ and the $\mathrm{RMSEA}=.073$

\subsection{Confirmatory Factor Analysis: Government Interventions}

Figures $6 \mathrm{a}$ and $6 \mathrm{~b}$ revealed the initial and revised CFA model for government intervention. Government interventions are variables that can be introduced to promote homeownership among the participants. Items measured include: INT1-government interventions encourage affordable housing supply INT2government helping people to possess their own houses, INT3absence of government interventions make people remain effective operations of Federal agencies concerned with housing will enhance homeownership. INT7- developing the private rental sector was better than government supply housing decision.

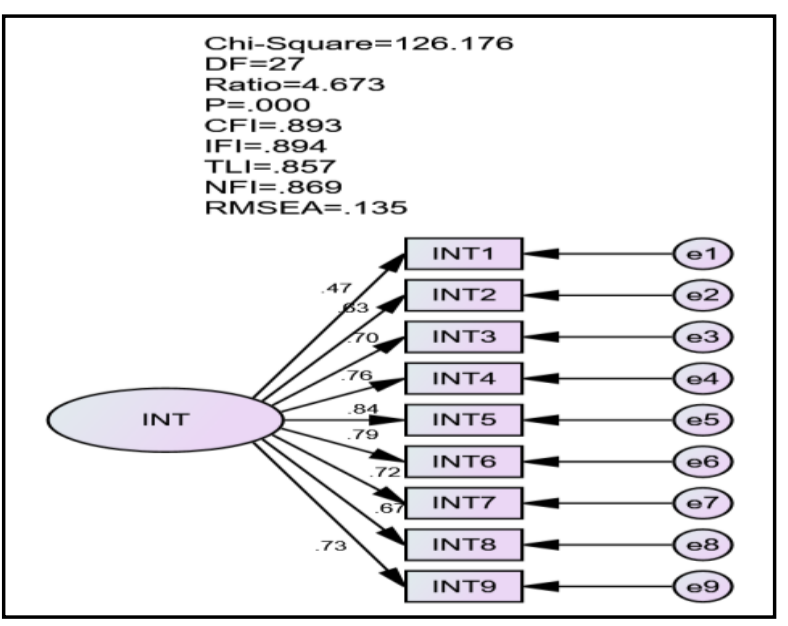

Figure 6a Initial CFA of Interventions

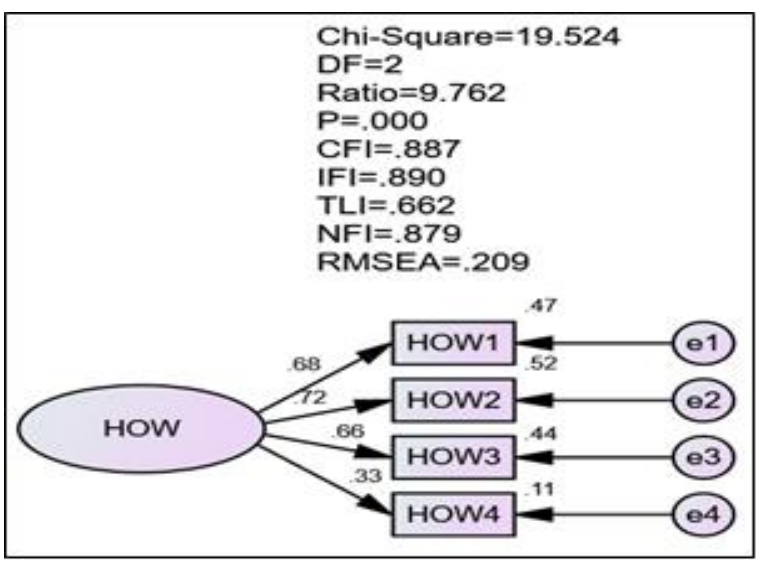

Figure 7a Initial CFA of Homeownership
The initial CFA model for government interventions did not meet the goodness fit criteria. INT1 was trimmed, and further model specifications were made by co-varying items INT3 and INT4 sequentially, and Items INT4 and INT 8. After the trimming of the models, the values obtained for the revised model is shown in Figure 6b, Chi-Square $=26.309 ; \mathrm{DF}=16$; Ratio $=1.644 ; \mathrm{P}=0.050$; $\mathrm{CFI}=.988 ; \mathrm{IFI}=.988 ; \mathrm{TLI}=.979 ; \mathrm{NFI}=.970 ; \mathrm{RMSEA}=.057$

\subsection{Confirmatory Factor Analysis: Homeownership Determinants}

Figures $7 \mathrm{a}$ and $7 \mathrm{~b}$ show the CFAs of homeownership determinants based on the responses of the real estate developers. The CFA did not conform to the goodness fit criteria The Chi-Square $=19.524$, $\mathrm{DF}=2$, Ratio $=9.762, \mathrm{P}=.000, \mathrm{CFI}=.887 ; \mathrm{IFI}=.890, \mathrm{TLI}=.662$ and NFI $=.879$, RMSEA .209. The items considered were; HOW1- marital status influence the rate of homeownership decisions, HOW2- investment in education and training delays the rate of homeownership, HOW3- investment in homeownership can guarantee future savings, HDS4- the pride of being a homeowner encourages investment in the housing sector. The covariance of items HOW1 and HOW4 shown in Fig. 7b improved the modification indices criteria. The results obtained are Chi-Square $=25.524, \mathrm{DF}=8$, Ratio $=3.191, \mathrm{P}=.001, \mathrm{CFI}=$ $.989, \mathrm{IFI}=.989, \mathrm{TLI}=.960$ and $\mathrm{NFI}=.984, \mathrm{RMSEA} .063$.

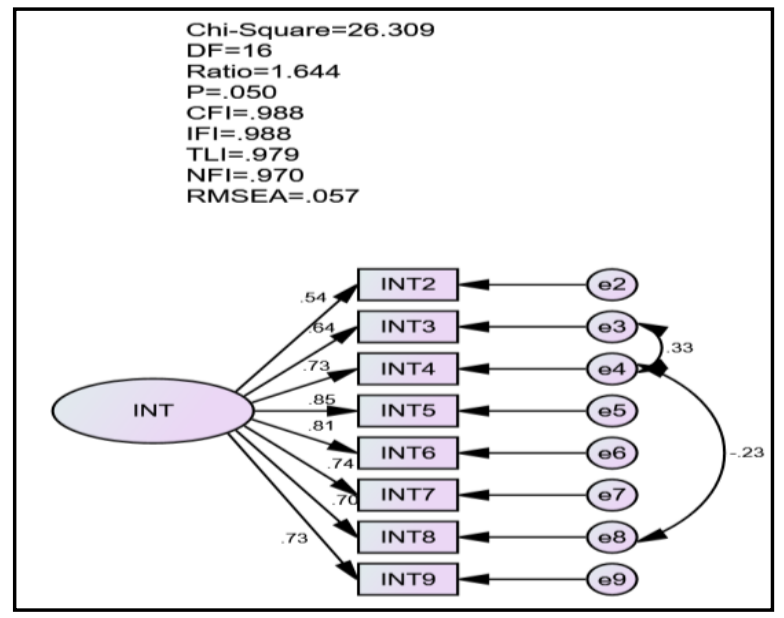

Figure 6b Revised CFA of Interventions

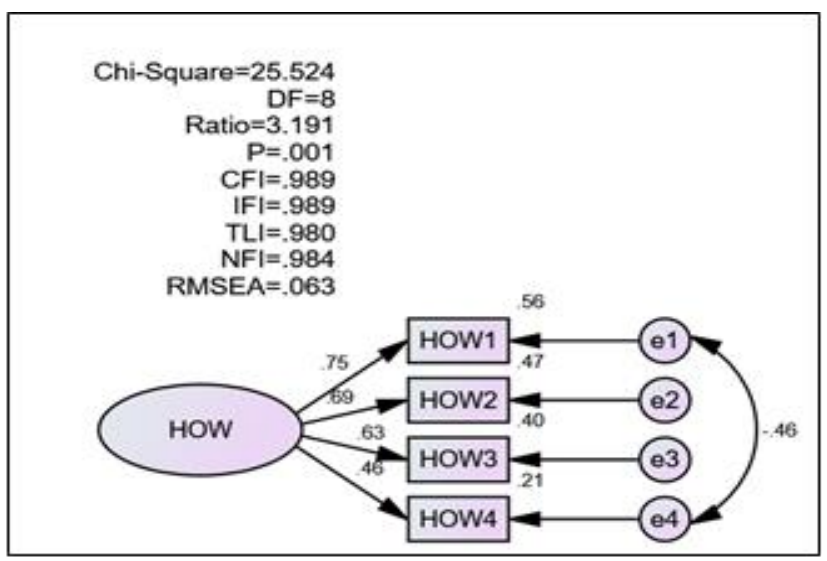

Figure 7b Revised CFA of homeownership 


\section{Conclusion}

The study reveals that accessibility of developers to land is one of the constraints affecting the housing supply process. The government does not usually provide infrastructural facilities such as roads, water, drainage and electricity that will aid the housing supply process. Land accessibility, availability of funding and demographics had significant and direct effects on affordable housing supply in Nigeria. The availability of subsidised land from the government was also revealed to be a factor in the construction of more affordable housing in Nigeria. The availability of communal land at low prices will increase housing production. The income level of households has an influence on the construction of affordable houses for homeownership by the real estate developers. Thirty-three per cent of households earn <USD2 per day. Large family size is prevalent where 50 per cent of respondents have a family size greater than 5 . About 42 per cent of the respondents live in rented housing. Government intervention did not contribute significantly to homeownership. The study indicates that the housing developers' ability to supply new homes is curtailed by their financial incapability, household's demographics and scarcity of land. The developers of affordable housing were constrained by rent and lack of collateral.

The study established that availability of funding, accessibility to subsidised or cheap land and demographic factors, constitute the main issues that urban housing providers must contend with in order to provide affordable housing in Nigeria. These findings are supported by Nubi (2008); Kuma (2015) and Agbola and Kasim (2007). These scholars assert that the lack of access to finance is a significant bottleneck to households and developers alike. Consequently, developers cannot participate meaningfully in the building process, either for rental or homeownership. The Presidential Committee on Urban Development and Housing (2001), recognised the seriousness in the shortage of suitable land for affordable housing. It concludes that the limitation to land for housing by potential developers could negatively interfere in the response of the housing market to any swift changes in the demand for more housing units in Nigeria. Affordable housing is achieved when strategies are put in place to support the proper supply of land suitable for development. There is, therefore, the urgent need for the government to adopt a genuine land reform in the country in order to make land more accessible to Nigerians in pursuance of this goal, serious attention must focus on the urgent need to review the Land Use Act promulgated in 1978.

Additionally, the governments of various states are directed to simplify and reduce the cost of obtaining consent to land transactions and building approvals. The main focus of the government should be to formulate a functional policy framework and to ensure the provision of the needed inputs and funding. If all these steps were taken into dire consideration, it would ultimately boost the systematic development of affordable housing in the country.

\section{Acknowledgements}

The authors sincerely acknowledge the Tertiary Education Trust Fund (TETFund) of the Government of Nigeria for the sponsorship of his $\mathrm{PhD}$ programme at the Universiti Teknologi Malaysia (UTM) enabling environment for beneficial study.

\section{References}

Abelson, P. (2009). Affordable Housing: Concepts and Policies. Economic Papers: A Journal of Applied Economics and Policy. 28(1): $27-$ 38.

Abdullahi, B. C. and Abd-Aziz, W. (2010). Nigeria 's Housing Policy and Public-Private Partnership (PPP) strategy: Reflections in Achieving Homeownership for Low-income Group in Abuja, Nigeria. Proceedings of the 22nd International Housing Research Conference. 4-7 July, Istanbul, Turkey.

Ademiluyi, A. I. \& Raji, B. A. (2008). Public and Private Developers as Agents in Urban Housing Delivery in Sub-Saharan Africa: The Situation in Lagos State. Humanity \& Social Sciences Journal. 3(2): 143-150.

Agbola, T.and Kasim, F (2007). Conceptual and Theoretical Issues in Housing. In: Agbola, T., Egunjobi, L. and Olatubara, C.O. (eds) Housing Development and Management: A Book of Readings. Department of Urban and Regional Planning, Faculty of Social Sciences, University of Ibadan, Nigeria, 156-169.

Agbola, T. and Olatubara, C. O. (1989). Housing Subsidy, Mortgage, Default and Housing Project Replicability in Nigeria: A Case Study of the Public Housing Delivery System. African Urban Quarterly. 4(1-2); 90-96. Agbola, Tunde and Adegoke, S. A. (2006). Housing Sector Reforms and Sustainable Development in Nigeria. Environ link, 1(1): 8.

Ajanlekoko, J. S. (2001). Sustainable Housing Development in NigeriaThe Financial and Infrastructural Implication. Proceedings of the International Conference on Spatial Information for Sustainable Development in Nairobi, Kenya. $2^{\text {nd }}-5^{\text {th }}$ October, Nairobi, Kenya

Ajibola M.O, Oluwunmi A.O and Eguh O. (2012). Examining the Factors Contributing to Affordable Housing in Kosofe Local Government Council Area Lagos, Nigeria, Journal of Asian Business Strategy. 2(10): 206-218

Akinmoladun, O. I. and Oluwoye, J. (2007). An Assessment of Why the Problems of Housing Shortages Persist in Developing Countries: A Case Study of Lagos Metropolis, Nigeria. Pakistan Journal of Social Science. 4(4); 589-598.

Alpopi C., Iacoboaea, C and Stănescu, A. (2014). Analysis of the Current Housing Situation in Romania in the European Context. Transylvanian Review of Administrative Sciences, 43(E): 5-24

Anayochukwu, O. B. (2011). Urban Housing Financing in the SouthEastern states of Nigeria: Problems and prospects. Journal of Sustainable Development in Africa, 13(8):268-282.

Aribigbola, A. (2006). Rational Choice Model and Housing Decisions in Akure, Ondo State, Nigeria. Confluence Journal of Environmental Studies. 1(1):53-63.

Australian Housing and Urban Research Institute (2012). How Great is the Affordable Housing Supply Crisis in Australia's Private Rental Market, 144. 
Awang, Z. (2014). A Handbook on Structural Equation Modelling. Selangor: MPWS Rich Publication.

Balchin, P. N.and Rhoden, M. (2002). Housing Policy: An Introduction. Psychology Press.

Blumenthal, P.M, McGinty, J.R and Pendall R. (2016). Strategies for Increasing Housing Supply in High-Cost Cities. Urban Institute Policy Advisory Group, 1 - 35

Carter, M. I. and Fuller C. (2015). Interactionism. Sociopedia.isa, California State University, Northridge, USA

Centre for Affordable Housing in Africa-CAHA (2015). A Review of Some Africa's Housing Finance Markets, Published by the Centre for Affordable Housing Finance in Africa. 183

City of Calgary (2008). City of Calgary: Corporate Affordable Housing Strategy. Calgary: City of Calgary, Corporate Properties and Community Strategies, 31.

Dung-Gwom, J.Y. and Mallo, D.M. (2011). An Appraisal of the Challenges of Accessing Credit for Home Acquisition by Low-Income Earners in Nigeria.

Emeka-Okereke, S. (2015). Nigeria's Housing Deficit: Stakeholders Task Government on Accurate Statistics: Real Estate \& Environment, January 13, National Mirror http://nationalmirroronline.net/new/nigerias-17mhousing-deficit-challenges-before-incoming-president/ Accessed on 29/12/2015

Gabriel, M, Jacobs K, Arthurson K, Burke T.and Yates J. (2005). Conceptualising and Measuring the Housing Affordability Problem, National Research Venture 3: Housing Affordability for Lower-Income Australians Research Paper No. 1, Australian Housing and Urban Research Institute.

Gilbert, A. (2004). Helping the Poor through Housing Subsidies: Lessons from Chile, Colombia and South Africa. Habitat international. 28(1): 13 40 .

Habte, A. G. (2010). An Assessment of Urban Housing Supply and Affordability in Jimma Town. With Special Reference to Condominium Housing, Munich, GRIN Verlag, https://www.grin.com/document/279819

Henshaw, G. (2010). The Role of the Private Sector in the Provision of Affordable Housing to the Public. Lecture Presented to the Nigerian Society of Engineers, CRS Branch, On Its 2010 Workshop.

Ibem, E. O., Anosike, M. N. and Azuh, D. E. (2011). Challenges in Public Housing Provision in the Post-Independence Era in Nigeria. Journal of Human Sciences. 8(2): 421-443.

Ibimilua A. F \& Ibitoye O. A. (2015). Housing Policy in Nigeria: An Overview. American International Journal of Contemporary Research, 5(2):23.

Ibrahim, K. and Mbamali, I. (2013). Availability of Housing Financing Funds for Private Estate Developers in Abuja, Nigeria. Sustainable Building Conference 2013, Coventry University.

Ifesanya, Ade-Kunle (2012). The Role of Government Agencies in Urban Housing Delivery Insufficient Political Will and Ineffective Housing Administration in Lagos Metropolis - Case Study of Ajegunle, Lagos, Institute for European Urban Studies, Faculty of Architecture, Bauhaus University Weimar, Germany, PhD Thesis
Jibril, I. (2009). Squatter Resettlement/Relocation Programme in Abuja, Nigeria and the Issue of Land Title Security. FIG Conference paper May $3^{\text {rd }}-8$ th. Eilat, Isreal.

Jimoh, R. A, Odeniyi, V. A and Jibrin, I. A. M. (2014). Housing Sustainability in Nigeria: A Mirage or Reality. Covenant Journal of Research in the Built Environment, 1(1):30-41

Kelly K., Clark B., Brown V. and Sitzia J. (2003). Good practice in the Conduct and Reporting of Survey Research. International Journal for Quality Health Care, 15(3): 261-266

Kuma, S. S. (2015). Assessing the Challenges of Access to Housing Finance in the North-Central States of Nigeria. Ethiopian Journal of Environmental Studies and Management, 8(2): 161-170.

Lagos State Ministry of Physical Planning (2010). Compendium of Housing Provisions and Development in Lagos.www.Lagos.gov.ng Lombard, J.J. G. (1996). Housing Strategies and the Urban Poor in South Africa: A Brief Critical Evaluation, Working paper No 80, July

Makinde, O. O. (2014). Housing Delivery System Need and Demand Environment, Development and Sustainability, 16(1): 49-69.

Melissa, K. S. and Turner, L. J. (2013). Giving Secondary Earners a Tax Break: A Proposal to Help Low and Middle-Income Families. Brookings.

McClelland, K. (2005). Symbolic interactionism, [Online] Available from: http://oak.cats.ohiou.edu [Accessed 14 April 2008]

Mojdeh, N. \& Abdollah, M. (2013). Improving the Quality of Affordable Housing: The Case of Mara in Famagusta City, North Cyprus, Turnkey. Recent Advances in Engineering Mechanics, Structures and Urban Planning

Nubi, O. T. (2008). Affordable Housing Delivery in Nigeria. South African Foundation International Conference and Exhibition, Cape Town.

Obi N. I. and Ubani O. (2014). Dynamics of Housing Affordability in Nigeria: Civil and Environmental Research, 6(3): 79-81

Onibokun, A. G. (1990). Urban Housing in Nigeria. Nigerian Institute of Social and Economic Research.

Oyinke, J. A. (2009). Addressing the Urban Housing Problems of Nigeria in the $21^{\text {st }}$ Century. Paper Presented at The $39^{\text {th }}$ Annual NIESV Conference.

Phang, S.Y., and M. Helble (2016). Housing Policies in Singapore. ADBI Working Paper 559. Tokyo: Asian Development Bank Institute. Available: http://www.adb.org/publications/housing-policies Singapore

Samad, D., Zainon N, Faizul Azli, F. Rahim M. Lou E, \& Abd Karim S.B. (2016). Malaysian Affordability Housing Policies Revisited. MATEC Web of Conferences https://www.researchgate.net/publication/305309415

Suhaida, M. S., Tawil, N. M., Hamzah, N., Che-Ani, A. I. and Tahir, M. M. (2010). A conceptual Overview of Housing Affordability in Selangor, Malaysia. Academy of Science, Engineering and Technology, 72, 45-47

Tabachnick, B. G. and Fidell, L. S. (2007). Using Multivariate Statistics, Fifth. Needham Height, MA: Allyn \& Bacon.

Taiwo D.O, Nooraini Y, Norsiah A.A, and Adams N.B. (2017), Unleashing the Potentials of the Housing Sector in Nigeria as Perceived by Users. International Journal of Built Environment and Sustainability, 4(3): 172-179 
Taiwo, D.O. (2018). Factors Influencing Affordable Housing Supply in Nigerian Cities, Faculty of Built Environment, Universiti Teknologi Malaysia. PhD Thesis.

Uganabo, C. U. and Emoh, F. I. (2013). The Major Challenges to Housing Development and Delivery in the Anambra State of Nigeria. Civil and Environmental Research, 3(4): 1-20.

UN-HABITAT (2001). The State of the World's Cities in 2001. United Nations for Human Settlements. Nairobi, Kenya.

UN-HABITAT (2011). Affordable Land and Housing in Africa Better Urban Future 3, United Nations Settlement Programme. Nairobi, Kenya

Utomo N. T. (2014). Affordable Housing Finance Policies in Indonesia. Washington DC, 28-29 May

Wheaton, B., Muthen, B., Alwin, D. F. and Summers, G. F. (1977). Assessing Reliability and Stability in Panel Models. Sociological Methodology. 8(1): 84-136.

Windapo, A.O. and Iyagba, R.O.A. (2007). Modelling the Determinants of Housing Construction Cost in Nigeria, in Brown, S. (ed.) COBRA Conference, The Royal Institution of Chartered Surveyors (RICS), Georgia Institute of Technology, 6-7 September [available at] http://www.rics.org/site/download_feed.aspx?fileID=3403\&fileExtensi on $=$ PDF World Bank Group (2014). $6^{\text {th }}$ Global Housing Finance Conference Housing for All, National Housing Policy of Mexico. The World Bank

World Bank Group (2015). Vietnam Affordable Housing: A Way Forward. The World Bank

\section{Appendix I}

\begin{tabular}{|l|l|l|}
\hline S/N & $\begin{array}{l}\text { FACTORS } \\
\text { INFLUENCING } \\
\text { AFFORDABLE } \\
\text { HOUSING } \\
\text { SUPPLY }\end{array}$ & SUPPORTING LITERATURES \\
\hline $\mathbf{1}$ & $\begin{array}{l}\text { Limited land } \\
\text { accessibility }\end{array}$ & $\begin{array}{l}\text { Nubi (2000), Oyinke (2009), } \\
\text { Akinmoladun (2007), Windapo et } \\
\text { al. (2007), Abdulahi } \text { et al. (2010), } \\
\text { Ademiluyi and Raji (2008) }\end{array}$ \\
\hline $\mathbf{2}$ & $\begin{array}{l}\text { Funding/ } \\
\text { finance }\end{array}$ & $\begin{array}{l}\text { Akinmoladun (2007), Oyinke } \\
\text { (2009), Uganabo } \text { et al. (2011), } \\
\text { Ifesanya (2012), Ibrahim and } \\
\text { Mbamali, (2013), Anayouchukwu } \\
\text { (2011) }\end{array}$ \\
\hline $\mathbf{3}$ & $\begin{array}{l}\text { Cost of } \\
\text { Construction }\end{array}$ & $\begin{array}{l}\text { Australian Housing and Urban } \\
\text { Research Institute (2007) Ademiluyi } \\
\text { and Raji (2008) }\end{array}$ \\
\hline $\mathbf{4}$ & $\begin{array}{l}\text { High population } \\
\text { growth and density }\end{array}$ & $\begin{array}{l}\text { Akinmoladun (2007), Ifesanya } \\
\text { (2012), Ibem } \text { et al. (2011) }\end{array}$ \\
\hline $\mathbf{5}$ & $\begin{array}{l}\text { Real income/ } \\
\text { affordability }\end{array}$ & $\begin{array}{l}\text { Ibem } \text { et al. (2011), } \\
\text { Ifesanya (2012) }\end{array}$ \\
\hline $\mathbf{6}$ & Demographics & $\begin{array}{l}\text { Un-Habitat (2007), City of Calgary, } \\
\text { (2008), Ajibola } \text { et al. (2012) }\end{array}$ \\
\hline $\mathbf{7}$ & $\begin{array}{l}\text { Provision of } \\
\text { Subsidies }\end{array}$ & $\begin{array}{l}\text { Agbola and Olatubara (1989), } \\
\text { Gilbert (2004) }\end{array}$ \\
\hline $\mathbf{8}$ & Tax Break & $\begin{array}{l}\text { Ifesanya (2012), Melissa } \text { et al. } \\
\text { (2013), }\end{array}$ \\
\hline $\mathbf{H}$ & Homeownership & $\begin{array}{l}\text { Ajanlekoko (2001), Jimoh } \text { et al } \\
\text { (2014), Suhaida } \text { et al (2010) }\end{array}$ \\
\hline
\end{tabular}

